\title{
Opportunistic infections in HIV positive patients in Bahrain in 4 years study 2009-2013
}

\author{
Nermin Saeed", Eman Farid, Afaf E Jamsheer \\ From International Symposium HIV and Emerging Infectious Diseases 2014 \\ Marseille, France. 21-23 May 2013
}

\section{Objectives}

This study aimed to examine the prevalence of opportunistic infections in HIV-infected patients in Bahrain and related them to the absolute CD4 count, CD $4 \%$ and CD4/CD8 ratio.

\section{Methods}

The research was a retrospective, cohort study using laboratory records from a major hospital in Bahrain, from January 2009 to May 2013. Opportunistic infections (OIs) and absolute CD4 count, CD4\% and CD4/ $\mathrm{CD} 8$ ratio were recorded for every patient.

\section{Results}

CD4\% and absolute CD4 count in HIV patients with associated infections was significantly lower than in those without associated infections $(\mathrm{P}<0.001)$ but there was no significant difference in CD4/CD8 Ratio between the two groups. Infection with Staphylococcus aureus was the commonest encountered infections and present in $9.8 \% \%$ of total AIDS patients and $28.7 \%$ of AIDS patient group who had OIs; followed by yeast infections (9.2\% and $27.2 \%$ respectively). Mycobacterium tuberculosis was present in $3.6 \%$ of total AIDS patients and $10.6 \%$ of the group with OIs while Mycobacterium Other Than Tuberculosis (MOTT) was present in 2.5\% and $7.5 \%$ respectively. Pneumocystis jirovecii pneumonia (PCP) was observed in $5.1 \%$ and $15.1 \%$ respectively. The least bacterial infections observed were Streptococcus penumoniae, Streptococcus melleri, Stenotrophomonas maltophilia, \& Citrobacter species. Herpes simplex II (HSV-II) was the commonest OIs observed while Cytomegalovirus antigenemia was only present in $2 \%$ and $6 \%$ respectively.

SMC, Pathology Department, Microbiology Section, Muharaq, Bahrain

\section{Conclusion}

Studying the pattern of OIs in HIV-infected patients in Bahrain is of paramount importance due to scarcity of data in the Arab worlds. This help to improve physician's awareness to improve care of AIDS patients.

Published: 23 May 2014

doi:10.1186/1471-2334-14-S2-P54

Cite this article as: Saeed et al:: Opportunistic infections in HIV positive patients in Bahrain in 4 years study 2009-2013. BMC Infectious Diseases 2014 14(Suppl 2):P54.
Submit your next manuscript to BioMed Central and take full advantage of:

- Convenient online submission

- Thorough peer review

- No space constraints or color figure charges

- Immediate publication on acceptance

- Inclusion in PubMed, CAS, Scopus and Google Scholar

- Research which is freely available for redistribution
() Biomed Central 